20. Bickmore K. Practicing conflict: Citizenship education in high school social studies. Unpublished disseration / K. Bickmore. - California : Stanford University, 1991.

21. Fisher R. Unveiling the hidden curriculum in conflict resolution and peace education: Future directions toward a critical conflict education and conflict pedagogy / R. Fisher. - Vancouver, BC, Canada : Research Institute, 2000.

22. Jaramillo N. Pedagogy of defiance: Public pedagogy as an act of unlearning. In J. Sandlin, B. Schultz, \& J. Burdick (Eds.). Handbook of public pedagogy: Education and learning beyond schooling / N. Jaramillo. - New York, NY: Routledge, 2010. - P. 500-510.

23. Graff G. Conflict pedagogy and student experience / G. Graff. - SSS, 1995. - P. 276-278.
24. Koshechko N.V. Actual ideas of pedagogical conflictology for preparation of educational professionals in domestic classical universities // Professional and pedagogical training of educational specialists in classical university of Ukraine: multi-authored monograph / Ed. by Marushkevich A.A. / N. V. Koshechko. - LAP LAMBERT Academic Publishing, 2019. - P. 89-110.

25. Kumashiro K. Troubling education: Queer activism and anti-oppressive pedagogy / K. Kumashiro. - London, UK : R-F, 2002.

26. Gutierez-Schmich T. Public Pedagogy and Conflict Pedagogy: Sites of Possibility for Anti-Oppressive Teacher Education. Electronic resource: https://scholarsbank.uoregon.edu/xmlui/bitstream/handle/1794/20490/Gutier ezSchmich.pdf?sequence $=4$

Надійшла до редколегії 04.11.19

N. Koshechko, Ph.D, Associate Professor

Taras Shevchenko National University of Kyiv, Kyiv, Ukraine

\title{
BASIC DIRECTLY OF PSYCHOLOGICAL CONSULTATION AT THE RESOLUTION OF THE INTERNAL CONFLICT STUDENTS AND TEACHERS: FOREIGN AND DOMESTIC EXPERIENCE
}

The article analyses current ideas on the problem of resolving internal conflicts of students and teachers, which become the basis for pedagogical conflicts in higher education. Particular emphasis is placed on the resource capabilities of psychological counselling in resolving intrapersonal conflicts. Different psychological areas, schools provide specific definitions, structure, and dynamics of psychological counselling. But the main focus is on improving the effectiveness of psychological counselling and the client's well-being. The counselling process can range from one to a number of psychological sessions. The consequences of counselling can be considered in terms of changes in the client's personality and the degree of his satisfaction with the results of counselling. In this process, special attention is paid to the eclectic consultative conversation. Its content, characteristics, principles, specifics, stages, stages are considered in detail. The functions, purpose, procedure of counselling in higher education are summarized, which is interpreted as a dynamic process during which the teacher-consultant helps the student to use their internal resources to develop and actualize the potential of meaningful life. Consultative conversation - the subject of subjective interaction, which is built and maintained in a partnership style; the purpose of which is mutual enrichment of experience, self-development of both parties and solving student problems. Internal conflicts, which are resolved constructively, have a positive effect on the individual, ensure his further professional growth, and inspire faith in themselves and in people. Knowledge and basic competencies in the dynamics, specifics of internal conflicts can save time, maintain productivity, health, and increase creativity, professional, intellectual and personal competence of students, teachers and heads of higher education institutions. Destructively resolved conflicts have the opposite and can lead to neurosis, depression, affective states, mental illness, which, in turn, are the basis for other somatic diseases. That is why it is so important to resolve conflicts with a positive consequence, which is caused, in particular, by the appropriate tools of psychological counselling.

Keywords: psychological counseling, solving of personal conflicts, pedagogical conflicts, students, teachers.

УдК 378.124

DOI: https://doi.org/10.17721/2415-3699.2020.12.06

Н. Кузьменко, д-р пед. наук, доц. Київський національний університет імені Тараса Шевченка, Київ, Г. Варварецька, асист., Національний університет "Одеська морська академія", Одеса

\section{ІМІДЖ-ОБРАЗ ВИКЛАДАЧА ЗАКЛАДУ ВИЩОЇ ОСВІТИ ЯК СКЛАДОВА ПРОФЕСІЙНО-ПЕДАГОГІЧНОї КУЛЬТУРИ}

Зазначено, що сучасними тенденціями освіти є модернізація ії змісту, форм і методів, розробка й апробація нових освітньо-психологічних технологій, появою нових типів закладів освіти. Ці зміни, у свою чергу, залежать від постійної роботи керівника закладу освіти над іміджем своєї установи, власним іміджем і репутації науково-педагогічних працівників. Розглянуто найбільш вагомі складові, без яких формування позитивного іміджу викладача вищої школи не вбачається можливим. Виявлено, що одним із чинників формування позитивного іміджу майбутнього фрахівця є освітнє середовище закладу вищої освіти $і$, зокрема, вплив професорсько-викладацького складу. Проаналізовано роль іміджу викладача у формуванні професійних і особистісних якостей студентів. Визначено сутність поняття педагогічного іміджу, його формування й розвиток, функиії іміджу, структура особистісного іміджу. Це, зокрема, професійна компетентність, загальнолюдські цінності, норми моралі, управлінська культура та технологія самопрезентації. Наведено приклади впливу зовнішнього вигляду викладача на рівень засвоєння навчальної інформації студентами. Встановлено зв'язок між компонентами іміджу та складовими педагогічної майстерності викладача закладу вищої освіти, визначено взаємозумовленість позитивного іміджу педагога та його гуманістичної спрямованості. Зазначено шляхи формування позитивного іміджу викладача й розвитку педагогічної майстерності. Визначено типи іміджу, охарактеризовано кінетичний і мовленнєвий імідж. Обґрунтовано, що позитивний педагогічний імідж викладача здатен сприяти підвищенню ефективності педагогічної діяльності та формувати стиль соціальної поведінки викладача вищої школи. Проаналізовано дослідження з цієї проблеми й останні публікації вітчизняних і зарубіжних науковців.

Ключові слова: професійно-педагогічна культура, педагогічний імідж, функції іміджу, складові іміджу, типи іміджу, самопрезентація.

Постановка проблеми. У сучасних умовах педагогічної гуманістичної орієнтації висуваються нові вимоги до професійно-педагогічної культури викладача. Його здатність до продуктивної інноваційної діяльності обумовлюється не лише існуванням власної творчої лабораторії, а й набуттям індивідуалізованого стилю професійної поведінки, взаємодії зі студентами, колегами. Завдяки цьому формується певний імідж-образ педагога, який відображає його особливий внутрішній світ. Такий образ створюється відповідно до бачення педагогом манер професійної діяльності, педагогічного спілкування, зовнішнього вигляду й активно впливає на формування його профе-сійно-педагогічної культури. Викладачеві треба володіти спеціальними технологіями самопрезентації, індивідуалізації власного стилю роботи задля того, щоб досягти визнання, підвищити репутацію, зміцнити авторитет, переконати громадськість у доцільності й корисності своєї діяльності. Практичний досвід показує, що інтерес студентів до навчальної дисципліни залежить від особи викладача, від глибини професійних знань і ерудиції; 
любові до педагогічної діяльності; педагогічної майстерності; громадського авторитету, стилю і принципів взаємостосунків між студентами та викладачами; науковоїпедагогічної активності й морально-етичних якостей. І саме зараз роль іміджології повинна посилюватися у зв'язку зі значним падінням престижу педагогічної професії в сучасних соціально-економічних умовах, необхідністю пошуку нових резервів матеріального і психологічного її стимулювання.

Аналіз останніх публікацій. Дослідженнями і практичними розробками з питань формування іміджу особистості займаються автори П. Берд, С. Блек, Ф. Буар, П. Вейл, Т. Сван, М. Спіллейн, Р. Хоффф, П. Чісхольм, Б. Швальбе й ін.; роль і значення іміджу в різних сферах соціального життя досліджують $€$. Богданов, А. Гармонова, У. Зазикін, З. Зотова, Є. Єгорова-Тантма, А. Панасюк, Ю. Синягин та ін.; іміджу вчителя присвячені роботи О. Деркача, Н. Кузьміної, А. Маркова, А. Реан та ін. Осмислення результатів вивчення ефекту самопрезентації та стратегій самоподачі, аналізу міжособистісного зворотного зв'язку, розробки ефективних психотехнологій збагачує дослідження іміджу (О. Анісімов, Р. Баумейстер, Дж. Готлі, Є. Гофрфман, Е. Джонс, Є. Доценко, В. Зазикін, С. Карвер, А. Кириченко, А. Панасюк, Л. Петровська, О. Соловйова, С. Уортман та ін.). Проблему формування професійного іміджу викладача вищої школи у вітчизняній психолого-педагогічній науці вивчали Ю. Андрєєва, Н. Бутейко, Д. Давидов, Л. Донська, А. Калюжний, Є. Петрова, В. Шепель.

Мета статті полягає в розкритті сутності поняття іміджу викладача вищої школи як складової його професійно-педагогічної культури. Для досягнення мети були поставлені завдання: дослідити взаємозв'язок між іміджем-образом викладача та професійно-педагогічною культурою.

Викладення основного матеріалу. У складний період реформування вищої освіти України та входження ії̈ до європейського освітнього простору набуває особливої актуальності проблема іміджу викладача закладу вищої освіти. У світлі перетворень, якими характеризуються всі сфери сучасного українського суспільства, дослідження проблеми іміджу викладача вищої школи набуває неабиякого практичного й теоретичного значення. Із-поміж багатьох чинників, які зумовлюють актуальність цієї роботи, варто зазначити такі: комунікативний імідж викладача $є$ складовою його професійної культури й показником педагогічної майстерності; особистісний імідж викладача як офріційного представника закладу вищої освіти - це невід'ємний компонент такого комплексного процесу як фрормування позитивного авторитету закладу освіти, що призводить до його успішності на ринку освітніх послуг; дослідження іміджу дає змогу встановити ступінь його впливу на соціальне самопочуття педагога, адекватність іміджу педагога системі освіти, яка перебуває під впливом соціально-економічних, політичних, ідеологічних, культурно-історичних та інших фракторів; позитивний імідж викладача забезпечує дотримання на практиці одного із визначальних принципів гуманістичної педагогіки - "принципу виховання особою". Вимоги до науково-педагогічних працівників висуваються не лише 3 боку держави, закладів вищої освіти, громадськості, а, найперше, самими студентами. I вони включають не лише якісне виконання навчальної та виховної функцій, а і вияв педагогічної майстерності, одним із показників якої є позитивний образ викладача.

Поняття педагогічного іміджу можна розглядати як категорію, що характеризує стиль професійно-педагогіч- ної діяльності, манеру спілкування, уміння індивідуалізувати свій образ, надати йому естетичної виразності. Ця функція педагогічної іміджології, що має на меті допомогти педагогові успішно презентувати власну особистість і оптимально використати свій творчий потенціал, є перспективним напрямом у сучасних дослідженнях проблем професійної культури викладача вищої школи.

У дослідженнях науковців професійно-педагогічна культура розглядається як важлива частина загальної культури, що виявляється в системі професійних якостей і специфіці педагогічної діяльності. Зокрема, дослідник I. Ісаєв вказує, що професійно-педагогічна культура об'єктивно існує не як можливість, а як реальна дійсність викладача, який здатний до творчого розмежування цінностей і технологій педагогічної діяльності і вносить свій вклад у її подальший розвиток [4]. Модель професійнопедагогічної культури, на його думку, містить чотири компоненти: аксіологічний, технологічний, евристичний та особистісний. Останній, тобто особистісний компонент моделі, варто розглянути в контексті теми статті.

Особистісний компонент розкриває професійно-педагогічну культуру викладача вищої школи як специфічний спосіб реалізації її сутнісних сил: потреби, здібності, інтереси, соціальний досвід особистості, ступінь її соціальної активності, отже, розкриває імідж-образ викладача. Педагогічна діяльність створює певні умови для творчої самореалізації особистості викладача, яка, у свою чергу, безпосередньо впливає на формування ціннісних орієнтацій студента.

Насамперед необхідно визначитись із змістом поняття "імідж викладача". Варто зазначити, що в літературі представлено безліч його дефрініцій, зокрема, "імідж" розглядається як "образ", причому під "образом" варто розуміти не лише візуальний, зоровий образ, а і спосіб мислення, дій, вчинків. Це й уміння спілкуватись, мистецтво говорити, а особливо слухати. Разом із тактом, освітою, діловими якостями наша зовнішність $€$ або продовженням наших достоїнств, або ще однією негативною рисою, що заважає життю та кар'єрі.

Як зазначає О. Вощевська, поняття "імідж" використовувалося ще за часів Аристотеля у фрілософському контексті. Термін "імідж" уперше з'явився в 1806 р. у словнику Ноя Вебстера. І́мідж (англ.image, від лат.imago, imitari - "імітувати") - штучна імітація або подання зовнішньої форми будь-якого об'єкта, особливо особи [3]. У англійському тлумачному словнику Longman "image - the opinion people have of a person, or the way the person seems to the public", що в перекладі означає думку інших людей про особу, якою вона $\epsilon$, або якою ії бачать інші люди [6]. Імідж людини формується, реалізується й розвивається у процесі діяльності. Володіння іміджевим механізмом важливо, насамперед, для людей публічних професій: політиків, журналістів, телеведучих, але головним чином педагогам, оскільки саме педагог доносить необхідну інформацію до студента та формує бажання (або небажання) вчитися.

В Україні цей термін увійшов у використання в освітній галузі наприкінці XX ст., оскільки демократизація суспільства призвела до необхідності розвитку зазначеного поняття не лише у сфері бізнесу, мистецтва, але й в освіті. У педагогіку поняття "імідж" прийшло з рекламної сфрери та із PR-сфери (Public Relations- зв'язки із громадськістю) і активно досліджується, починаючи з 90-х pp. минулого століття. Водночас, освітяни часто ігнорують важливість поняття "імідж", тому є нагальна потреба у створенні правильного позитивного іміджу викладача вищої школи. 
У латинсько-російському словнику Й. Дворецького [2, с. 375] дається декілька його значень, із-поміж яких вкажемо такі: 1) зображення; 3) образ; 4) відображення; 5) вид, видимість; 6) мисленнєвий образ, уявлення, поняття, ідея. Найчастіше під іміджем педагога розуміють сукупність зовнішніх і внутрішніх особистісних, індивідуальних і професійних якостей, які забезпечують ефективність педагогічної діяльності. Імідж педагога - це інтегративна якість особистості, синтез інтелектуальної, габітарної, кінетичної, мовленнєвої, матеріальної, соціальної й артистичної культури, що $є$ багатофрункціональною системою, виступаючи найважливішим компонентом педагогічної майстерності. Досліджуючи імідж педагога 3 позиції гештальтпсихології, українська дослідниця Т. Туркот виокремлює такі його компоненти [5]: 1) професіоналізм і компетентність; 2) ерудиція; 3) творча енергія; 4) високий рівень загальної й педагогічної культури; 5) психологічно-індивідуальні якості (емпатія, чуйність, рефлексивність, доброзичливість, уміння запобігати конфліктів; 6) міцне фрізичне і психічне здоров'я; 7) зовнішня естетична привабливість (бездоганна охайність, доречний одяг, макіяж, прикраси, хода, постава, привітні посмішка, вираз обличчя). Отже, це поняття пов'язане не лише із зовнішнім виглядом, але й із внутрішнім змістом людини, її психологічним типом.

Вважаємо, що професійний імідж викладача необхідно розглядати як образ, що формується внаслідок соціальної перцепції, коли об'єктом сприйняття виступає сам викладач, а суб'єктами сприйняття - студенти, колеги, адміністрація або інші особи, з якими викладач спілкується у процесі здійснення профресійної діяльності.

На думку В. Олексенка, імідж викладача вищої школи - інтегральна характеристика, яка включає в себе сукупність зовнішніх і внутрішніх особливостей, особистісних, індивідуальних і професійних якостей педагога, що сприяють ефективності педагогічної діяльності. Професійний імідж викладача - це образ професійної ролі, яка конструюється самим викладачем і доповнюється індивідуальним іміджем у процесі взаємодії зі студентами, колегами, адміністрацією й товариством [6].

Ефективність освітнього процесу багато в чому залежить від того, наскільки адекватним ситуації $€$ педагог і яким сприймають його студенти. Важливою частиною іміджу педагога є й те, якою мірою йому притаманне красномовство. Спілкуючись зі студентами, викладач не повинен забувати про тон, яким він розмовляє. Від цього залежить не лише емоційний стан слухачів, але і їхня працездатність. Правильно вибраний тон розмови, тембр голосу, витонченість рухів багато в чому визначають образ, у якому педагог постає перед людьми. Дослідження показують, що більшість із них звертають увагу насамперед на зовнішність викладача, його манеру триматися і пов'язують із ними професійно значущі особистісні якості викладачів. Для багатьох людей інформація, отримана від зорового образу, є єдиним "банком даних" про людину, і на цій підставі вони вибудовують свої відносини з іншими людьми. І чим точніше створений образ викладача, тим легше спілкуватися з ним і менше сил він потребуватиме, щоб знайти спільну мову зі студентами.

Так званий "невербальний" імідж пов'язаний із приємними манерами, жестами, мімікою, позою. Хороші манери допомагають швидко адаптуватись у будь-якій обстановці, спрощують встановлення комунікаційних зв'язків з людьми [7].

Зовнішнім відображенням особистості ідеального викладача в очах студентів виступає поєднання людських і професійних якостей. При цьому при знайомстві зовні- шні якості (вербальні й невербальні) виносяться на перший план. Образ педагога включає в себе вміння спілкуватися, мистецтво говорити і, що дуже важливо, слухати. Також для позитивного образу педагога має значення зовнішній вигляд. Викладач усім своїм зовнішнім виглядом повинен викликати до себе прихильність студентів і колег. Візуальна привабливість - першорядна складова іміджу. Значення має і кольорова гама костюму, і відповідний макіяж, і елегантна зачіска. У манері одягатися проявляється одне з головних правил: красиво виглядати - значить проявляти повагу до оточуючих людей [2]. Викладач всім своїм зовнішнім виглядом повинен викликати до себе прихильність студентів і колег.

Професійні якості педагога повинні відповідати таким вимогам психолого-педагогічної діяльності: поважати у студентові особистість; постійно шукати можливість саморозвитку та самовдосконалення; передавати знання так, щоб студент хотів і міг їх засвоювати, був готовий їх використовувати в різних ситуаціях. Викладач зобов'язаний бути особистістю. Тільки особистість виховує особистість, тільки характер формує характер.

Спеціальні здібності в педагога такі: спостережливість, здатність швидко орієнтуватися в ситуації, інтуїцію, емпатію, рефлексію і самоконтроль. Для успішного розвитку студента, викладач має створити відповідну атмосфреру. Здатність до цього і визначає професіоналізм викладача.

Американський вчений М. Тален виділив такі типи професійних позицій педагога: "Сократ" - педагог із репутацією шанувальника дискусій і суперечок; "керівник групової дискусії"; "майстер" - педагог є взірцем для наслідування; "генерал" - вимогливий, чітко слідкує за слухняністю, тому що вважає себе завжди правим; "менеджер" - стиль, у якому педагог заохочує ініціативу й самостійність студентів у розв'язуванні навчальних завдань; "тренер" - атмосфера спілкування пронизана духом корпоративності, педагог $€$ натхненником групових зусиль; "гід" - педагог є образом "ходячої" енциклопедії, але часто відверто нудний [1]. В ідеалі викладач вищої школи повинен уміти поєднувати всі зазначені типажі.

На жаль, багато хто з викладачів, особливо старшого покоління, занижують значення іміджу, вважаючи, що основне завдання педагога - навчити студентів предмету, при цьому мовлення викладача, його зовнішній вигляд, одяг, манери є питанням другорядним. Водночас через економічну ситуацію в нашій країні та ще через ряд причин спостерігається зниження престижності професії викладача. Випускники педагогічних закладів вищої освіти доволі часто влаштовуються на роботу в міжнародні організації, які дбають про свій авторитет на ринку праці, надаючи своїм працівникам можливості для формування та вдосконалення іміджу. Викладачі закладів вищої освіти покладаються в цьому питанні на власний досвід і можливості. Однак не варто забувати, що імідж викладача впливає на імідж закладу освіти, що не може не відобразитися на його популярності у потенційних абітурієнтів.

Високо оцінюючи весь спектр позитивних якостей викладача, студенти все-таки визначають для них своєрідну ієрархію: якості, що характеризують рівень знання викладача; якості, які виявляються в міжособистісних стосунках; особистісні якості; зовнішні характеристики. Серед особистісних якостей найважливішими студенти визнають чуйність, чутливість, уважність, стриманість, вимогливість, об'єктивність, справедливість, чесність, принциповість, скромність, життєрадісність, почуття гумору. 
Соціальне визнання й оцінка професійних досягнень педагога соціумом впливають на формування його самосвідомості, самооцінки та самореалізації. Самосвідомість і самооцінка сприяють появі у викладача почуття впевненості, оптимізму, що, у свою чергу, сприяє успішній побудові професійно-педагогічної кар'єри і самореалізації викладача. Презентуючи власний імідж, викладач демонструє студентам себе як особистість, своє ставлення до оточуючих, очікування від інших. Правильно підібраний імідж і манери самопрезентації викладача не лише полегшують досягнення стратегічних цілей, але й впливають на формування особистого іміджу студентів і закладу вищої освіти загалом.

Імідж $є$ динамічною системою, оскільки є результатом постійної роботи особистості над собою. На нього впливають природні якості, життєвий і професійний досвід, виховання й освіта. Імідж педагога - це емоційно забарвлений стереотип сприйняття образу педагога у свідомості студентів, колег, соціального оточення, у масовій свідомості. При формуванні іміджу педагога реальні якості тісно переплітаються з тими, які приписуються йому оточуючими [3]. Імідж, у будь-якому разі, - результат свідомої роботи. Особливо він стосується ситуації, де він $є$ частиною професійного успіху [8].

Профресія педагога потребує створення іміджу і через потреби ринкової економіки. Уже не достатньо бути просто професіоналом. Особистий імідж педагога є важливим доповненням або необхідною умовою його ефективної діяльності. Саме тому формувати свій імідж педагогу необхідно значно прискіпливіше, ніж спеціалістам інших професій, тому що саме педагоги формують імідж своїх студентів і $є$ для них взірцем. Це важливо враховувати викладачам у роботі зі студентами різних спеціальностей, а особливо, на нашу думку, імідж викладача відіграє важливу роль при підготовці майбутніх менеджерів освіти, оскільки, вони спроєктують подальший успішний (або не зовсім вдалий) розвиток як освітньої галузі, так і всього суспільства в цілому. Актуальність підготовки керівників освітянської галузі ОР "магістр" зумовлена сучасними вимогами до змісту освіти, що $є$ результатом євроінтеграційних процесів і нового бачення функцій закладу освіти щодо духовного й інтелектуального розвитку суспільства. Натепер загальновизнано, що освіта не лише соціальний інститут, а й сфера специфічних послуг; що управління в освіті в нових економічних відносинах не може базуватися на командно-адміністративному стилі, оскільки керівник закладу освіти повинен володіти сучасними технологіями підвищення якості навчально-виховного процесу й забезпечувати комфортні умови праці та саморозвитку педагогічних працівників. Зараз управлінська діяльність розглядається як діяльність професійна. Із цим пов'язане впровадження в науковий простір поняття "менеджер освіти", у межах якого керівник освітнього закладу розглядається як професіонал, здатний не лише з максимальною ефективністю реалізувати себе, але й забезпечити реалізацію наявних індивідуальних здібностей, інтелектуальних і моральних можливостей своїх підлеглих із мінімальними витратами часу й зусиль. Формування й подальший розвиток управлінця як менеджера освіти нині можливі лише на засадах спеціальної професійної підготовки, поєднання в ній науково-теоретичних досягнень вітчизняної педагогічної науки, організаційно-технологічних розробок, передової практики, здобутків провідних світових шкіл менеджменту, що забезпечить високий рівень компетентності керівника освіти та неперервність його підготовки й розвитку як менеджера - висококваліфікованого професіонала, освітнього лідера світового рівня. Діяльність такого менеджера потребує й іміджевої підтримки, цілеспрямованої роботи щодо формування його репутації.

Висновки. Отже, педагогічний імідж-образ викладача вищої школи має стати органічною складовою професійно-педагогічної культури, яка спрямована на створення позитивної громадської думки щодо змісту педагогічних ідей та інновацій, підкреслюючи їхню оригінальність, доцільність для широкого запровадження. Імідж, представляючи собою багаторівневу багатофункціональну систему, є найважливішим компонентом педагогічної майстерності викладача вищої школи. Він забезпечує процес професійної соціалізації через процес самовдосконалення й розвитку - до самопред'явлення себе суспільству. Позитивний імідж викладача сьогодні важливий не лише для його студентів - як особистий приклад успішної людини, а й для самого педагога для моральної, психологічної задоволеності професійною діяльністю.

Список використаних джерел

Буланова-Топоркова В. М. Педагогика и психология высшей школы : учеб. пособие / В. М. Буланова-Топоркова. - Ростов/н/Д : Феникс, 2002

Вощевська О. В. Зміст і процес підготовки інженерів-аграрників у вищій школі США : монографія / О. В. Вощевська. - Ніжин : ТОВ "Видавництво "Аспект-Поліграф", 2011.

Імідж. Wikipedia [Електронний ресурс] - Режим доступу: https://uk.wikipedia.org/wiki//мідж

Исаев И. Ф. Профессионально-педагогическая культура преподавателя / И. Ф. Исаев. - М. : Академия, 2002

Кулакова Т. Б. Имидж педагога как социокультурный феномен : автореф. дисс. на соискание уч. степени канд. психол. наук / Т. Б. Кулакова. - М. : Знание, 2007.

Олексенко В.П. Формування професійного іміджу сучасного вчителя [Електронний ресурс] / В. П. Олексенко - Формування професійного іміджу сучасного вчителя. - Режим доступу: http://ekhsuir.kspu.edu/ bitstream/формування професійного іміджу.pdf

Навроцька М. М. Розвиток професійного іміджу педагога в системі післядипломної педагогічної освіти: дис. на здобуття наук. ступ. канд. пед. н.: 13.00.04. / М. М. Навроцька. Тернопільський нац. пед. ун-т імені В. Гнатюка. - Тернопіль, 2019.

Чебикін О. Я. Психологічні особливості формування основ професійного іміджу : монографрія / О. Я. Чебикін, О. О. Ковальова. - О. Півд. наук. центр АПН України, 2009.

\section{References}

Bulanova-Toporkova V.M. Pedahohyka y psykholohyia vыsshei shkolы Uchebnoe posobye / V. M. Bulanova-Toporkova. - Rostov/n/D : Fenyks, 2002.

Voshchevska O. V. Zmist i protses pidhotovky inzheneriv-ahrarnykiv u vyshchii shkoli SshA : monohrafiia / O. V. Voshchevska. - Nizhyn : TOV "Vydavnytstvo "Aspekt-Polihraf", 2011.

Imidzh. Wikipedia [Elektronnyi resurs] - Rezhym dostupu: https://uk.wikipedia.org/wiki/lmidzh

Ysaev Y. F. Professyonalno-pedahohycheskaia kultura prepodavatelia / Y. F. Ysaev. - M. : Akademyia, 2002

Kulakova T. B. Ymydzh pedahoha kak sotsyokulturnы fenomen: avtoref. dyss. na soyskanye uch. stepeny kand.. psykholoh.nauk / T. B. Kulakova. M., 2007.

Oleksenko V. P. Formuvannia profesiinoho imidzhu suchasnoho vchytelia [Elektronnyi resurs] / V. P. Oleksenko - Formuvannia profesiinoho imidzhu suchasnoho vchytelia. - Rezhym dostupu: http://ekhsuir.kspu.edu/ bitstream/formuvannia profesiinoho imidzhu.pdf

Navrotska M. M. Rozvytok profesiinoho imidzhu pedahoha $v$ system pisliadyplomnoi pedahohichnoi osvity: dys. na zdobuttia nauk. stup. kand ped. n.: 13.00.04 / M. M. Navrotska. Ternopilskyi nats. ped. un-t imeni V. Hnatiuka. - Ternopil, 2019.

Chebykin O. Ya. Psykholohichni osoblyvosti formuvannia osnov profesiinoho imidzhu : Monohrafiia / O. Ya. Chebykin, O. O. Kovalova. Odesa : Pivd. nauk. tsentr APN Ukrainy, 2009.

Надійшла до редколегії 13.01.20 
N. Kuzmenko, Doktor of Pedagogical Sciences, Professor of Pedagogy Department

Taras Shevchenko National University of Kyiv, Kyiv, Ukraine

G. Varvaretska, assistant

National University "Odessa maritime University", Odesa, Ukraine

\section{THE HIGHER SCHOOL TEACHER'S IMAGE AS A COMPONENT OF PROFESSIONAL AND PEDAGOGICAL CULTURE}

The article points out that the modern tendencies of education are the modernization of it's content, forms and methods, development and testing of new educational and psychological technologies, the emergence of new types of educational institutions. These changes, in turn, depend on require the constant work of the head of the educational institution over the image of their institution, their own image and the reputation of research and teaching staff. The article deals with the most important components without which the formation of a positive image of a high school teacher is not possible. It was revealed that one of the factors for creating a positive image of the future specialist is the educational environment of the higher education institution and, in particular, the influence of the teaching staff. The role of the teacher's image in the formation of students' professional and personal qualities was analyzed. The essence of the concept of pedagogical image, its formation and development, functions of image, structure of personal image are determined. These include, in particular, professional competence, universal values, moral standards, managerial culture and technology of self-presentation. The article provides examples of the influence of the teacher's appearance on the level of information assimilation by students. The connection between the components of the image and the components of the teacher's pedagogical skill of the institution of higher education was established, the interdependence of teacher's positive image and his or her humanistic orientation was determined. The ways of formation teacher's positive image and development of pedagogical skill are outlined. The types of public image are defined, kinetic and speech image are characterized. The article substantiates that the teacher's positive pedagogical image is able to promote the rise of the efficiency of pedagogical activity and is able to shape the style of social behavior of the high school teacher. Research on this problem and recent publications of domestic and foreign scientists are analyzed.

Keywords: professional and pedagogical culture, education manager, pedagogical image, image functions, components of the image, types of image, kinetic image, speech image, self-presentation.

удк 378

DOI: https://doi.org/10.17721/2415-3699.2020.12.07

А. Марушкевич, д-р пед. наук, проф. Київський національний університет імені Тараса Шевченка, Київ

\section{ЗАБЕЗПЕЧЕННЯ ЯКОСТІ ОСВІТИ В СУЧАСНОМУ ЗВО: АКТУАЛЬНІ ІДЕЇ}

Розглянуто актуальні ідеї щодо забезпечення якості освіти в закладах вищої освіти України; наголошено на їі суттєвих характеристиках $і$ важливості взаємоузгодження навчальних планів у вітчизняних $і$ зарубіжних 3ВО; обґрунтовано суть понять "якість освітньої діяльності" та "якість вищої освіти", "академічна спільнота", "університетська спільнота", "антикорупційна програма"; доведено значення взаємодії викладачів і студентів у процесі навчання.

Ключові слова: якість освітньої діяльності, якість вищої освіти, компетентності, університетська спільнота, академічна спільнота, викладачі, студенти.

Постановка проблеми. Україна, як незалежна суверенна держава, співпрацює з багатьма країнами світу у справі поліпшення своєї економічної, політичної, культурної складових забезпечення життєдіяльності народу. Важливою в цій співпраці є підтримка освітньої галузі, яка реформується й оновлюється шляхом налагодження зв'язків із закладами освіти далекого і близького зарубіжжя. Це спрямування потребує від ії̈ науково-педагогічної спільноти забезпечення оптимальних умов для індивідуального розвитку особистості, її духовного потенціалу. Відповідно, у Законах України "Про вищу освіту" (2014), "Про освіту" (2017) висуваються вимоги щодо формування у молоді здатності до комунікацій, професійних якостей і навичок, які сприятимуть у досягненні нею цілей та успіху в реалізації своїх можливостей на ринку праці. У зв'язку з цим в Україні здійснюється докорінна зміна підходів до забезпечення освіти, зокрема вищої, зумовлена орієнтацією суспільства на розвиток мобільної, здатної до змін в особистісних і культурних якостях відповідно до вимог часу людини. Це викликане змінами у суспільній свідомості, оціночному ставленні народу щодо фуннкціонування й розвитку освітньої сфери, її ролі у творенні нової, спрямованої на вдосконалення особистості системи надання освітніх послуг, зосередженої на підтримці саморозвитку особистості, виробленні в неї необхідних якостей для професійної діяльності. Суттєвими характеристиками вищої освіти в нинішніх умовах $€$ її динамічність та інтернаціональність. Спостерігається розширення доступу до навчання у ЗВО не лише громадян України, а й представників інших країн, їхня рівність щодо вступу. Особлива увага держави звернена на поліпшення якості вищої освіти, що суттєво впливає на забезпечення ринку праці висококваліфрікованими фрахівцями, спроможними протистояти викликам часу.
Мета публікації полягає в розгляді актуальних ідей щодо забезпечення якості вищої освіти в Україні з урахуванням вимог сучасного суспільства до навчання здобувачів вищої освіти у ЗВО.

Завдання публікації - розкрити актуальні ідеї забезпечення якості вищої освіти в Україні; обґрунтувати необхідність якісного навчання здобувачів вищої освіти для їхньої конкурентоздатності на ринку праці у прийдешньому.

Аналіз останніх досліджень і публікацій. Проблема забезпечення якості вищої освіти в Україні вивчається й аналізується представниками різних галузей наукового знання. Натепер опубліковано значна кількість наукових праць, у яких автори намагаються висвітлити проблеми та шляхи їхнього подолання в освітній галузі, аналізують запозичений світовий досвід навчання і виховання студентів, їхньої професійної підготовки й реалізації як самодостатніх фахівців на ринку праці. Ідеї забезпечення якості вищої освіти знаходимо у працях відомих українських учених В. Андрущенка, І. Беха, С. Домбровської, П. Клімової, К. Корсака, В. І. Лугового, Ж. Таланової та ін. Ними зацікавлена велика кількість молодих дослідників: аспірантів і докторантів. Розглядають ці питання в дипломних роботах випускники ЗВО. Із цього бачимо, що проблема $є$ актуальною й до кінця не вивченою.

Викладення основних положень. Європейський і світовий освітній простір орієнтується на таку складову характеристики якості функціонування ЗВО як мобільність його студентів, науково-педагогічних працівників, керівного складу. У цьому руслі професійна підготовка здобувачів вищої освіти включає взаємоузгодження навчальних планів, що сприяє адаптації студентів до умов навчання не лише у вітчизняних закладах вищої освіти, а і у відповідних 3ВО інших країн та уможливлює отримання подвійних дипломів. 